\title{
Việt Nam tăng trưởng học thuật nhanh nhất kể từ 2009: Báo cáo toàn cầu về nghiên cứu khoa học tại Đông và Nam Á
}

\author{
Hồ Mạnh Toàn \\ Al for Social Data Lab (AISDL)
}

05-10-2019

Dựa trên dữ liệu của Web of Science, Institute for Scientific Information (ISI) đã công bố báo cáo Global Research Report - South and East Asia [1], ngày 1-10-2019, đánh giá chi tiết tiềm năng chưa được khám phá hết của nghiên cứu khoa học tại khu vực Đông và Nam Á. Báo cáo đã công bố đầy đủ tình hình năng suốt nghiên cứu, hợp tác quốc tế, và ảnh hưởng học thuật của 14 quốc gia tại khu vực này, bao gồm: Lào, Myanmar, Brunei, Campuchia, Sri Lanka, Philippines, Bangladesh, Indonesia, Thái Lan, Pakistan, Malaysia, Singapore, Ấn Độ và Việt Nam.

Về năng suất khoa học, dữ liệu từ Web of Science cho thấy kể từ năm 2000, sản lượng nghiên cứu tại Đông và Nam Á đã tăng trưởng mạnh, hiện tại đóng góp 8\% tổng số lượng công bố toàn cầu hàng năm. Việt Nam là quốc gia trong khu vực có sự tăng trưởng nhanh nhất, với lượng công bố được chỉ mục hóa tăng đã tăng gấp năm lần kể từ năm 2009.

Ngoài ra, báo cáo cũng tính toán giá trị Category-Normalised Citation Impact hay $\mathrm{CNCl}$. Đây là hệ số trung bình phản ánh ảnh hưởng học thuật của một công bố dựa trên số lần công bố được trích dẫn bởi các công bố khác. Bởi vì số trích dẫn của các nghiên cứu ở các lĩnh vực khác nhau sẽ có sai khác phụ thuộc theo xu thế của từng ngành, vì thế, giá trị được chuẩn hóa $\mathrm{CNCl}$ sẽ giúp độc giả có khả năng so sánh số liệu ở mức độ tổng quan.

Hai hệ số được báo cáo sử dụng là $\mathrm{CNCl-gross} \mathrm{(tính} \mathrm{tất} \mathrm{cả} \mathrm{các} \mathrm{bài} \mathrm{báo} \mathrm{có} \mathrm{sự} \mathrm{xuất}$ hiện của một quốc gia) và $\mathrm{CNCl}$-domestic (không tính các công bố có hợp tác quốc tế). Trong giai đoạn 2014-2018, Việt Nam có có $C N C l$-gross $=1.20$ và CNCl-domestic $=0.67$ (Trung bình toàn cầu $=1.0$ ).

Sự tăng trưởng của sản lượng công bố tại Đông và Nam Á có sự đóng góp đáng kể từ quá trình hợp tác giữa các quốc gia trong khu vực và với các nền khoa học phát 
triển hơn. Theo đánh giá của các tác giả, hợp tác học thuật tại khu vực có sự tăng trưởng tốt là nhờ thông tin về các hội nghị được tiếp cận dễ dàng hơn, việc di chuyển cũng thuận tiện hơn; các dự án quốc tế trong các lĩnh vực lớn hiện nay như sức khoẻ, môi trường, hay vật lý cũng cung cấp thêm nhiều cơ hội cho các nhà khoa học; và đặc biệt là tính chất toàn cầu của các vấn đề khoa học hiện nay.

Bên cạnh đó, mạng lưới hợp tác quốc tế của khu vực Đông và Nam Á được báo cáo đồ thị hoá như ở hình dưới. Có thể thấy, Việt Nam có sự kết nối với hầu hết các nền khoa học phát triển trên thế giới như Mỹ, Pháp, Anh, hay trong châu Á như Nhật Bản, Đài Loan, Trung Quốc hay Hàn Quốc.

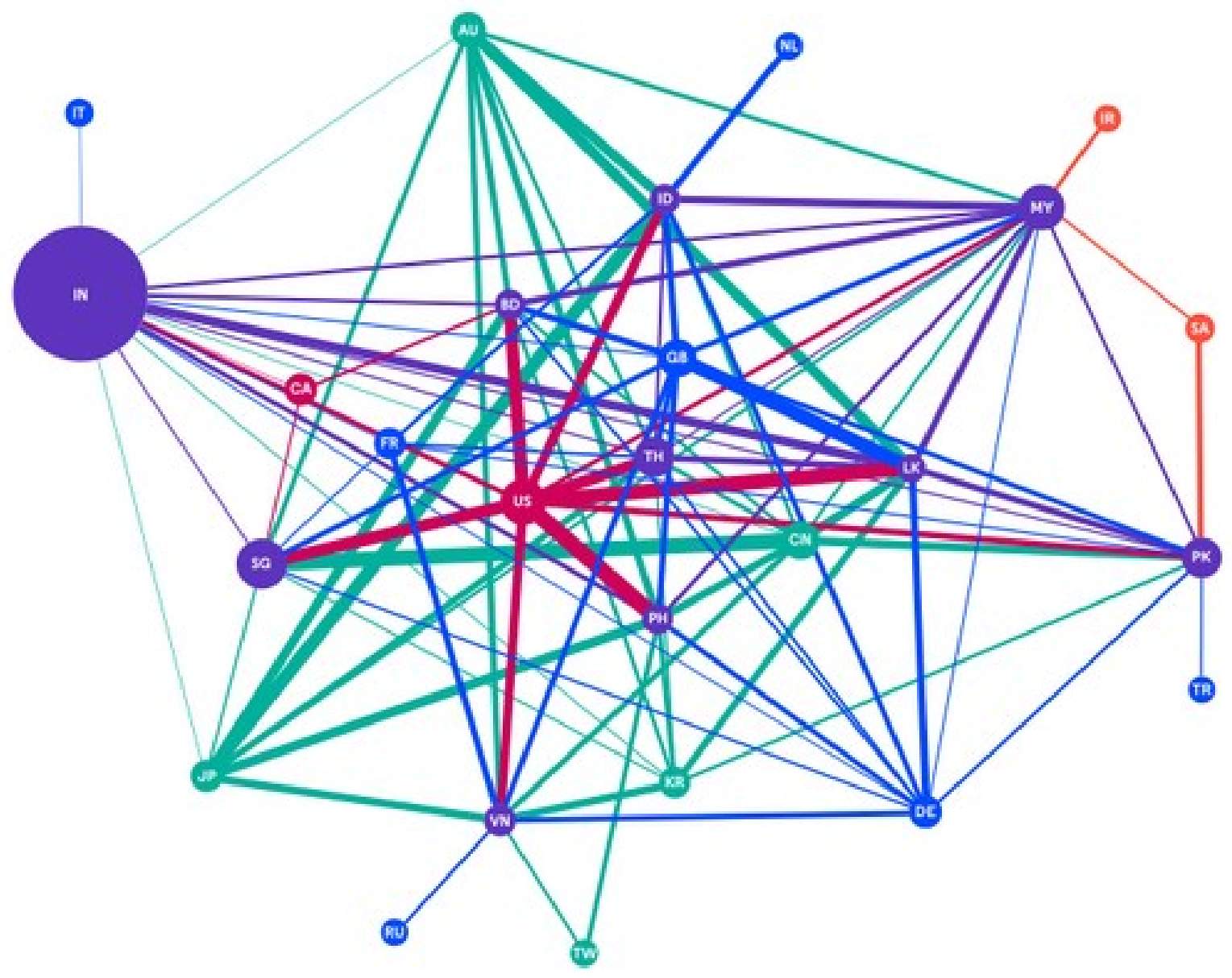

Hồ sơ ảnh hưởng (Impact Profiles) thể hiện phân phối của giá trị CNCl trong giai đoạn 2009 - 2018. Trong giai đoạn này, Việt Nam có tổng cộng 26,742 bài báo được chỉ mục hoá, nhưng chỉ có 5,859 bài báo là do người Việt đứng tên hoàn toàn. 
Bên cạnh đó, cũng có đến 35\% các bài báo toàn Việt là thuộc nhóm chưa bao giờ được trích dẫn, so với $25 \%$ tổng cộng và $22 \%$ các bài báo hợp tác quốc tế.

\section{Vietnam}

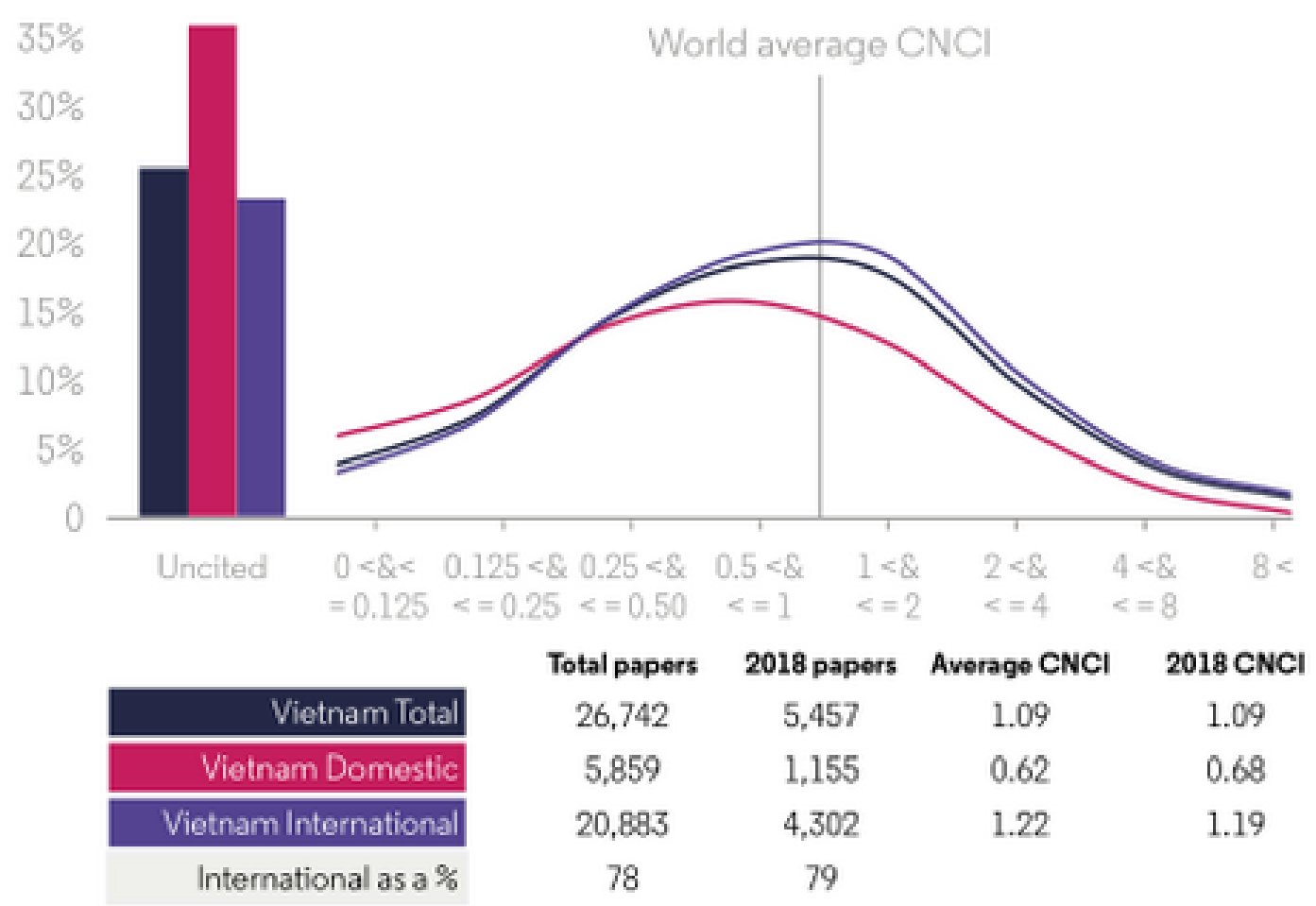

Mặc dù vậy, nhóm tác giả cũng cho biết có rất nhiều nghiên cứu nhằm phục vụ nhu cầu của địa phương và khu vực, vì thế công bố của các nghiên cứu này có thể không đăng trên các tạp chí chỉ mục hoá bởi Web of Science.

Báo cáo cho thấy nghiên cứu tại khu vực Đông và Nam Á vẫn cần nhiều thời gian để có thể đuổi kịp các quốc gia châu Âu hay các nền khoa học phát triển tại châu Á. Nhóm tác giả gợi ý 3 yếu tố chính sẽ góp phần thúc đầy khoa học tại khu vực này: nhân sự, môi trường nghiên cứu, và nguồn lực đầu tư cho khoa học và giáo dục.

Tham khảo thêm cho từng khu vực, báo cáo Global Research Report - South and East Asia cũng trích dẫn và gợi ý các tài liệu tham khảo bổ sung của các nhà nghiên cứu từ các quốc gia trong khu vực.

Bốn bài nghiên cứu của các tác giả Việt Nam được gợi ý bao gồm: 


\begin{tabular}{|l|c|}
\hline \multicolumn{1}{|c|}{ Article } & Ref. Item \\
\hline $\begin{array}{l}\text { International collaboration in scientific research in Vietnam: an analysis } \\
\text { of patterns and impact }\end{array}$ & {$[2]$} \\
\hline $\begin{array}{l}\text { Scientific output and its relationship to knowledge economy: an } \\
\text { analysis of ASEAN countries }\end{array}$ & {$[3]$} \\
\hline $\begin{array}{l}\text { Faculty development in Southeast Asian higher education: a review of } \\
\text { literature }\end{array}$ & {$[4]$} \\
\hline $\begin{array}{l}\text { The harsh world of publishing in emerging regions and implications for } \\
\text { editors and publishers: The case of Vietnam }\end{array}$ & {$[5]$} \\
\hline
\end{tabular}

Trong đó, hai bài viết của tác giả Nguyễn Văn Tuấn là các nghiên cứu trắc lượng khoa học về Việt Nam và các nước ASEAN. Hai tác phẩm còn lại các các bài rà soát tổng quan chi tiết về phát triển đội ngũ giảng viên tại giáo dục đại học Đông Nam Á, và sự phát triển của xuất bản học thuật tại Việt Nam. Với tính chất là một báo cáo toàn cầu, các tác phẩm được nhóm tác giả gợi ý chắc hẳn đều có tính đại diện cao, chạm đến một cách đầy đủ các vấn đề về nghiên cứu và phát triển học thuật tại mỗi quốc gia. Bên cạnh các tác phẩm này, SSHPA xin được giới thiệu thêm một số tác phẩm có giá trị khác:

\begin{tabular}{|l|c|}
\hline \multicolumn{1}{|c|}{ Article } & Ref. Item \\
\hline $\begin{array}{l}\text { Scientific publications in Vietnam as seen from Scopus during 1996- } \\
2013\end{array}$ & {$[6]$} \\
\hline $\begin{array}{l}\text { On the sustainability of co-authoring behaviors in Vietnamese social } \\
\text { sciences: A preliminary analysis of network data }\end{array}$ & {$[7]$} \\
\hline $\begin{array}{l}\text { Nemo solus satis sapit: Trends of research collaborations in the } \\
\text { Vietnamese social sciences, observing 2008-2017 Scopus data }\end{array}$ & {$[8]$} \\
\hline $\begin{array}{l}\text { Academic governance and leadership in Vietnam: Trends and } \\
\text { challenges }\end{array}$ & {$[9]$} \\
\hline Breaking barriers in publishing demands a proactive attitude & {$[10]$} \\
\hline $\begin{array}{l}\text { The (ir)rational consideration of the cost of science in transition } \\
\text { economies }\end{array}$ & {$[11]$} \\
\hline $\begin{array}{l}\text { A comparative study of research capabilities of East Asian countries and } \\
\text { implications for Vietnam }\end{array}$ & {$[12]$} \\
\hline
\end{tabular}


Note: An earlier version of this appeared in EASE Vietnam SciComm System: https://sc.sshpa.com/post/5563

\section{References:}

[1] Adams, J., Pendlebury, D., Rogers, G., \& Szomszor, M. (2019). Global research report on South and East Asia. Institute for Scientific Information. Retrieved from https://clarivate.com/webofsciencegroup/campaigns/south-and-east-asia/ (Accessed: 05-10-2019).

[2] Nguyen, T. V., Ho-Le, T. P., \& Le, U. V. (2017). International collaboration in scientific research in Vietnam: an analysis of patterns and impact. Scientometrics, 110, 1035-1051.

[3] Nguyen, T. V., \& Pham, L. T. (2011). Scientific output and its relationship to knowledge economy: an analysis of ASEAN countries. Scientometrics, 89, 107117.

[4] Phuong, T. T., Duong, H. B. \& McLean, G. N. (2015). Faculty development in Southeast Asian higher education: a review of literature. Asia Pacific Education Review, 16, 107-117

[5] Vuong, Q. H. (2019). The harsh world of publishing in emerging regions and implications for editors and publishers: The case of Vietnam. Learned Publishing, 32(4), 314-324.

[6] Manh, H. D. (2015) Scientific publications in Vietnam as seen from Scopus during 1996-2013. Scientometrics, 105, 83-95.

[7] Ho, M. T., et al. (2017). On the sustainability of co-authoring behaviors in Vietnamese social sciences: A preliminary analysis of network data. Sustainability, 9(11), 2142, doi: 10.3390/su9112142.

[8] Vuong, Q. H. et al. (2017). Nemo solus satis sapit: Trends of research collaborations in the Vietnamese social sciences, observing 2008-2017 Scopus data. Publications, 5(4), 24, doi: 10.3390/publications5040024.

[9] Salmi, J., \& Pham, T. L. (2019). Academic governance and leadership in Vietnam: Trends and challenges. Journal of International and Comparative Education, 8(2), 103-118, doi: 10.14425/jice.2019.8.2.103. 
[10] Vuong, Q. H. (2019). Breaking barriers in publishing demands a proactive attitude. Nature Human Behaviour, 3, doi: 10.1038/s41562-019-0667-6

[11] Vuong, Q. H. (2018). The (ir)rational consideration of the cost of science in transition economies. Nature Human Behaviour, 2(1), 5, doi: 10.1038/s41562017-0281-4.

[12] Hien, P. D. (2010). A comparative study of research capabilities of East Asian countries and implications for Vietnam. Higher Education, 60(6), 615-625, doi: 10.1007/s10734-010-9319-5. 